\title{
Studies on the Functional Relationship between $\phi$ X174 and S13 Coded Proteins Using an In Vitro DNA Synthesis System
}

\author{
Kounosuke Watabe, Tetsuro Kuga, Hiroshi SaKaI \\ and Tohru Komano \\ Laboratory of Biochemistry, Department of Agricultural Chemistry, \\ Kyoto University, Kyoto 606, Japan
}

Received April 6, 1981

\begin{abstract}
The functional relationship between bacteriophage $\phi X 174$ and $S 13$ gene products was investigated using an in vitro DNA synthesis system in two stages: (a). replication of the closed circular duplex form DNA (RF to RF) and (b) synthesis of single-stranded DNA from RF and formation of the intermediate $50 \mathrm{~S}$ complex in phage morphogenesis ( $\mathrm{RF}$ to $50 \mathrm{~S}$ complex). Partially purified gene A products of $\phi \mathrm{X} 174$ and S13 were able to function reciprocally in the stage from RF to $\mathrm{RF}$ replication. In the stage of $\mathrm{RF}$ to $50 \mathrm{~S}$ complex, extracts from Escherichia coli infected with $\phi X 174$ catalyzed the formation of 50S complex from S13 RF DNA. Extracts from E. coli infected with S13 also had the ability to catalyze the formation of 50S complex from $\phi$ X174 RF DNA. Thus, all gene products required for DNA replication and phage morphogenesis were found to function reciprocally between $\phi \mathrm{X} 174$ and $\mathrm{S} 13$.
\end{abstract}

Bacteriophages S13 and $\phi \mathrm{X} 174$, small circular single-stranded DNA phages, were isolated independently and have been shown to be serologically related. $\left.{ }^{1} \sim 3\right)$ Their DNAs are almost identical in physical characteristics. ${ }^{4}$ Genetic recombination can take place among some mutants, ${ }^{5)}$ and all but one of S13 or $\phi \mathrm{X} 174$ gene products complement their $\phi \mathrm{X} 174$ or $\mathrm{S} 13$ counterpart in in vivo complementation test. ${ }^{6)}$ The phage-coded proteins are found to be similar to each other in profiles of polyacrylamide gel electrophoretic patterns. ${ }^{7,8)}$

Despite these similarities, S13 and $\phi \times 174$ show rather high degree of divergency in base sequence. Godson reported that there was up to a $35 \%$ base mismatching under stringent denaturation conditions in heteroduplex analysis, and that only $4.7 \pm 1.9 \%$ of the DNA of $\phi \mathrm{X} 174$ is highly homologous with $\mathrm{S} 13$ DNA. ${ }^{9)}$ Recently, Compton and Sinsheimer observed less homology than did Godson under mild denaturation conditions and more homology under stringent conditions. ${ }^{10)}$ DNA fragments produced by many restriction en-

\footnotetext{
Abbreviations: RF, replicative form; RFI, covalently closed circular RF; RFII, open circular RF.
}

zymes are also slightly different. ${ }^{11)}$ It is reported that the host dependency is different between these phages. ${ }^{12)}$ Therefore, it is assumed that the mechanism of DNA replication is different between the two phages. In terms of functional relationship in DNA synthesis, it is important to know how many phage-coded proteins can be exchangeable between the two phages.

In vitro systems for DNA synthesis of $\phi X 174$ have been developed and revealed the mechanism of DNA synthesis in three stages, (I) conversion of circular single-stranded parental DNA to the duplex replicative form (SS to RF), (II) replication of the closed circular duplex form (RF to RF) and (III) synthesis of single-stranded DNA from RF and formation of the intermediate 50S complex in the phage morphogenesis (RF to $50 \mathrm{~S}$ complex). ${ }^{13 \sim 16)} \mathrm{In}$ stage (II), only $\phi \mathrm{X} 174$ gene A product is required in addition to host proteins, as was first shown by Tessman for the S13. ${ }^{14 \sim 16)}$ In stage (III), all phage-coded gene products except for gene $\mathrm{E}$ is required. ${ }^{177}$ In this work the functional relationship of gene products of $\phi \mathrm{X} 174$ and S13 was investigated using in vitro DNA synthesis system in stage (II) and (III). It 
is shown that all gene products except for gene $\mathrm{E}$ of $\mathrm{S} 13$ and $\phi \mathrm{X} 174$ are reciprocally functioning.

\section{MATERIALS AND METHODS}

Bacterial and phage strains. E. coli $\mathrm{H} 560$ (polA, endA, thy $A$ ) was used for the preparation of protein fractions. Phage $\phi \mathrm{X} 174 a m 3$, a lysis-defective mutant $\phi \mathrm{X} 174, \mathrm{~S} 13$ wild type (obtained from Dr. Tessman) and fd wild type were used.

Nucleotides. Unlabeled deoxyribonucleotide triphosphates (dNTPs) and ribonucleotide triphosphates (rNTPs) were obtained from Boehringer Mannheim $\mathrm{GmbH}$. [Methyl- $\left.{ }^{3} \mathrm{H}\right]$ dTTP was purchased from New England Nuclear Corporation.

Preparation of protein fractions. Protein fractions capable of promoting the replication of RF to RF and RF to $50 \mathrm{~S}$ complex were prepared by the method of Wickner $e t$ al. and of Yasumoto et al., respectively, except for the following modifications. ${ }^{17.19)}$ (a) For preparation of uninfected ammonium sulfate fraction, E. coli $\mathrm{H} 560$ was grown at $37^{\circ} \mathrm{C}$ in L-broth medium supplemented with $50 \mu \mathrm{g} / \mathrm{ml}$ thymine to a cell density of 0.6 absorbance unit at $610 \mathrm{~nm}$. Cells were lysed and the lysate was centrifuged at $24,000 \mathrm{rpm}$ for $45 \mathrm{~min}$ in a Hitachi RPS 25 rotor at $2^{\circ} \mathrm{C}$ (b) For preparation of phage infected protein fractions (Fraction II), E. coli $\mathrm{H} 560$ was grown in TPG-CA medium supplemented with $50 \mathrm{\mu g} / \mathrm{ml}$ thymine at $30^{\circ} \mathrm{C}$ to a cell density of 0.3 absorbance unit at $610 \mathrm{~nm}$. Cells were infected with $\phi \mathrm{X} 174$ or $\mathrm{S} 13$ for $25 \mathrm{~min}$ in order to prepare Fraction II, which is required for the replication of RF to $\mathrm{RF}$, and for $50 \mathrm{~min}$ to prepare Fraction II, which is required for the formation of $50 S$ complex. Cells were lysed and the lysate was centrifuged in a Hitachi RPS 40T rotor at $32,000 \mathrm{rpm}$ for $30 \mathrm{~min}$ to obtain Fraction II for $\mathrm{RF}$ to RF synthesis system and for $90 \mathrm{~min}$ to prepare Fraction II for RF to $50 \mathrm{~S}$ complex formation system.

Protein fractions prepared by the above method were frozen in small portions at $-20^{\circ} \mathrm{C}$.

Preparation of DNA. RFI DNAs of $\phi \mathrm{X} 174, \mathrm{~S} 13$ and fd were prepared by the procedure of Komano and Sinsheimer. ${ }^{20)}$

Reaction mixture. The standard reaction mixture $(50 \mu \mathrm{l})$ contained $50 \mathrm{~mm}$ Tris $\cdot \mathrm{HCl}(\mathrm{pH} 7.5), 10 \mathrm{~mm} \mathrm{MgCl}_{2}, 4 \mathrm{~mm}$ DTT, $1 \mathrm{~mm}$ ATP, $0.2 \mathrm{~mm} \mathrm{NAD}{ }^{+}, 40 \mu \mathrm{M}$ each of dATP, dGTP, dCTP and [methyl $\left.{ }^{3} \mathrm{H}\right]$ dTTP $(200$ $\mathrm{cpm} / \mathrm{pmol}$ ), $0.1 \mathrm{~mm}$ each of CTP, UTP and GTP, $1 \mu \mathrm{g}$ of RFI DNA, $2 \mathrm{~mm}$ spermidine- $3 \mathrm{HCl}, 240 \mu \mathrm{g}$ protein of uninfected ammonium sulfate fraction and $60 \mu \mathrm{g}$ protein of Fraction II. Spermidine-3HCl was omitted from the reaction mixture for RF to $50 \mathrm{~S}$ complex analysis.
The reaction mixture was incubated at $30^{\circ} \mathrm{C}$. The reaction was stopped by adding ice-cold trichloroacetic acid (TCA) to the final concentration of $10 \%$. The precipitates formed were collected onto Whatman GF/C glass filter discs, and were washed with ice-cold $5 \%$ TCA and then with ice-cold ethanol. The dises were dried and counted for radioactivity by a Beckman liquid scintillation counter. When reaction products were characterized by sedimentation analysis, the reaction was stopped by adding EDTA and Sarkosyl or only EDTA as described by Yasumoto. ${ }^{17)}$

Sedimentation analysis. Products were analyzed by one of sucrose gradient centrifugation described as follows;

(I) A neutral 5 to $20 \%$ linear sucrose gradient containing $50 \mathrm{~mm}$ Tris $\cdot \mathrm{HCl}(\mathrm{pH} 7.4), 0.5 \mathrm{M} \mathrm{NaCl}$ and $3 \mathrm{~mm}$ EDTA was centrifuged in a Hitachi RPS $40 \mathrm{~T}-2$ rotor at $37,000 \mathrm{rpm}$ for $4.5 \mathrm{hr}$ at $2^{\circ} \mathrm{C}$.

(II) An alkaline 5 to $20 \%$ linear sucrose gradient containing $0.5 \mathrm{M} \mathrm{NaCl}, 3 \mathrm{~mm}$ EDTA, $0.1 \%$ sarkosyl and $0.3 \mathrm{~N} \mathrm{NaOH}$ on a cushion of $0.2 \mathrm{ml}$ of $55 \% \mathrm{CsCl}$ solution was centrifuged in a Hitachi RPS $40 \mathrm{~T}-2$ rotor at 39,000 rpm for $3 \mathrm{hr}$ at $2^{\circ} \mathrm{C}$.

(III) A neutral 5 to $30 \%$ linear sucrose gradient containing $20 \mathrm{~mm}$ Tris $\cdot \mathrm{HCl}$ ( $\mathrm{pH} 7.4$ ), $5 \mathrm{~mm}$ EDTA, $0.1 \mathrm{M}$ $\mathrm{NaCl}$ on a cushion of $0.5 \mathrm{ml}$ of $55 \% \mathrm{CsCl}$ solution was centrifuged in a Hitachi RPS $40 \mathrm{~T}$ rotor at $39,000 \mathrm{rpm}$ for $2.5 \mathrm{hr}$ at $2^{\circ} \mathrm{C}$.

Isolation and characterization of product DNA. The reaction mixture for $\mathrm{RF}$ to $50 \mathrm{~S}$ complex system was centrifuged in a neutral 5 to $30 \%$ sucrose gradient as described above. Fractions corresponding to $50 \mathrm{~S}$ or $20 \mathrm{~S}$ regions of the sucrose gradient were pooled, $10 \mathrm{~mm}$ EDTA and $0.2 \%$ SDS (final) were added to each pooled fraction and the mixture was heated at $60^{\circ} \mathrm{C}$ for $15 \mathrm{~min}$ followed by a $3.5 \mathrm{hr}$ incubation at $37^{\circ} \mathrm{C}$ with auto-digested proteinase $\mathrm{K}(1 \mathrm{mg} / \mathrm{ml})$. The mixtures were dialyzed against $50 \mathrm{~mm}$ Tris $\cdot \mathrm{HCl}(\mathrm{pH} 8.0)$ containing $5 \mathrm{~mm}$ EDTA for $12 \mathrm{hr}$. The purified DNA was analyzed by 5 to $20 \%$ sucrose gradient centrifugation as described above.

\section{RESULTS}

\section{Replication of $R F$ to $R F$}

Fraction II prepared from $E$. coli infected with S13 incorporated dTMP into S13 DNA in the presence of uninfected ammonium sulfate fraction (normal reaction). This reaction depended on RFI DNA added exogenously and Fraction II (Table I). When RF DNA of phage fd was used as a template in place of $\mathrm{S} 13$ RF DNA, no incorporation of dTMP was observed. Omission of dNTPs, ATP or $\mathrm{Mg}^{2+}$ abolished the activity. CTP, GTP and UTP 
TABLE I. REQUIREMENTS FOR RF TO RF SYSTEM

\begin{tabular}{|c|c|c|c|}
\hline \multirow{2}{*}{$\begin{array}{l}\text { Omission or } \\
\text { addition }\end{array}$} & \multicolumn{3}{|c|}{ dTMP Incorporation $(\%)$} \\
\hline & $\begin{array}{c}\text { Fraction II: } \phi X 174 \\
\text { DNA: S13 }\end{array}$ & $\begin{array}{l}\text { Fraction II: S13) } \\
\text { DNA: } \phi \text { X174 }\end{array}$ & $\begin{array}{c}\text { Fraction II: S13 } \\
\text { DNA: S13 }\end{array}$ \\
\hline Complete & $100^{a}$ & $100^{b}$ & $100^{c}$ \\
\hline$-D N A$ & 15 & 11 & 12 \\
\hline - Fraction II & 21 & 20 & 23 \\
\hline$-\mathrm{Mg}^{2+}$ & 9 & 5 & 5 \\
\hline - rATP & 35 & 28 & 33 \\
\hline -dATP, dCTP, dGTP & 24 & 25 & 26 \\
\hline - rCTP, rGTP, rUTP & 116 & 96 & 100 \\
\hline $\begin{array}{l}+ \text { rifampicin } \\
(100 \mu \mathrm{g} / \mathrm{ml})\end{array}$ & 131 & 101 & 108 \\
\hline $\begin{array}{l}+\mathrm{NEM}^{d} \\
(10 \mathrm{mM})\end{array}$ & 13 & 16 & 15 \\
\hline $\begin{array}{l}+\mathrm{PCM}^{e} \\
(10 \mathrm{mM})\end{array}$ & - & - & 14 \\
\hline $\begin{array}{l}+\mathrm{fd} R F \\
-\mathrm{S} 13 \text { or } \phi \mathrm{X} R \mathrm{~F}\end{array}$ & 14 & 14 & 15 \\
\hline
\end{tabular}

Assay conditions were described in MATERIALS AND METHODS. The reaction mixture was incubated for $40 \mathrm{~min}$ at $30^{\circ} \mathrm{C}$. One-hundred percent $\left[{ }^{3} \mathrm{H}\right]$ dTMP incorporation corresponds to: ${ }^{a} 12.0$ pmol; ${ }^{b} 12.2$ pmol; ${ }^{c} 11.0$ pmol; ${ }^{d} \mathrm{~N}$-Ethylmaleimide; ${ }^{e} p$-Chloromercuriphenylsulfonate.

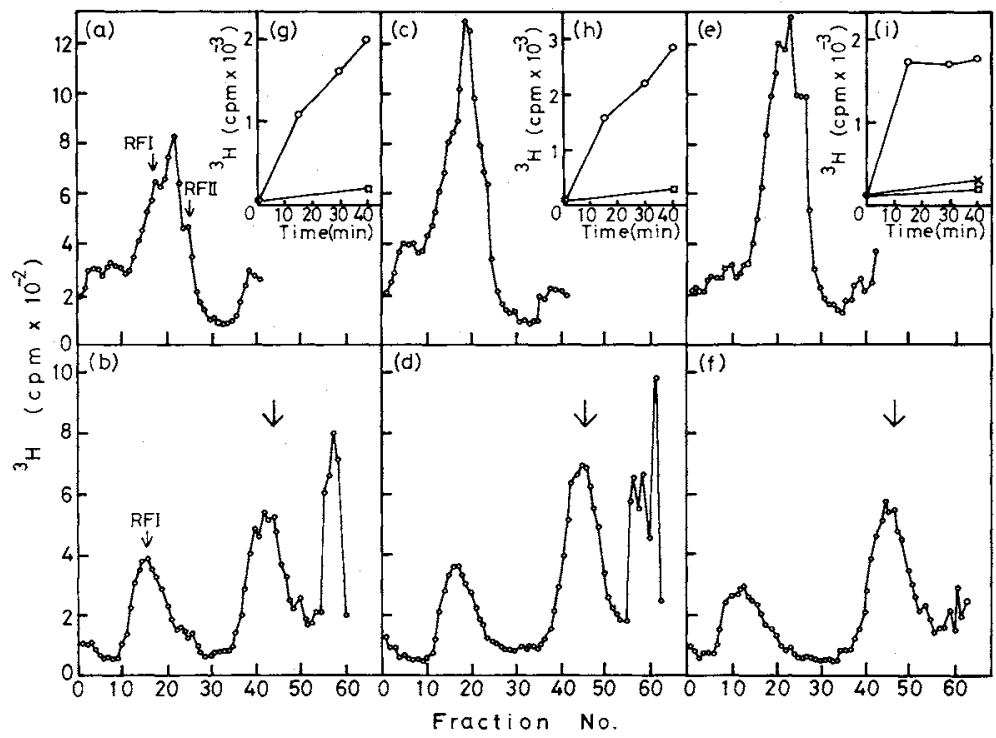

FIG. 1. Kinetics of dTMP Incorporation and Product Analysis of the RF to RF System.

The complete reaction mixture $(200 \mu 1)$ was incubated for $40 \mathrm{~min}$ at $30^{\circ} \mathrm{C}$ and the product was analyzed by sucrose gradient sedimentation. Reaction product of $\phi$ X174 RF DNA and Fraction II prepared from S13infected cells were sedimented in a sucrose gradient I (a) or II (b) as described in MATERIALS AND METHODs. Reaction products of S13 RF DNA and Fraction II prepared from $\phi$ X174-infected cells were sedimented in a sucrose gradient I (c) or II (d). Reaction products of S13 RF DNA and Fraction II prepared from S13-infected cells were sedimented in a sucrose gradient I (e) or II (f). Fractions $41 \sim 48$ were discarded because no acidinsoluble radioactivity was detected ( $\mathrm{a}, \mathrm{c}$ and $\mathrm{e}$ ). The arrow indicates the position of $\phi \times 174$ single-stranded circular DNA. Inserted figures represent kinetics of $\left[{ }^{3} \mathrm{H}\right]$ dTMP incorporation into acid-insoluble materials $(\mathrm{g}$, $\mathrm{h}$ and i). $\bigcirc-O$, complete reaction mixture; $\square-\square$, RF DNA was omitted; $x-\times$, fd RF DNA was used in place of S13 or $\phi \mathrm{X} 174 \mathrm{RF}$ DNA. 
were not required. DNA synthesis was abolished by $N$-ethylmaleirimide (NEM) or $p$ chloromercuriphenylsulfonate (PCM) but not by rifampicin.

Fraction II prepared from $E$. coli infected with $\phi \mathrm{X} 174$ incorporated dTMP into S13 RF DNA. Fraction II from S13-infected $E$. coli also incorporated dTMP into $\phi \mathrm{X} 174 \mathrm{RF}$ DNA (exchanged reaction). These reactions showed the same characteristics as that of normal reaction (Table I).

Products of these reactions were analyzed by centrifugation through neutral and alkaline sucrose gradients (Fig. 1). In neutral sucrose gradient centrifugation the incorporated radioactivity was distributed over three major components as shown in Fig. 1a, c and e. The faster sedimenting component corresponded to RFI, the component sedimented in the middle corresponded to sigma type DNA and the slower sedimenting component corresponded to RFII. A small amount of rapidly sedimenting components was also detected. When products were analyzed by alkaline sucrose gradient centrifugation, RFI, singlestranded DNA longer than unit length sedimenting slightly faster than marker DNA
( $\phi$ X174 single-stranded circular DNA) and single-stranded circular DNA were detected. Small DNA fragments of approximately 5 to $10 \mathrm{~S}$ were also detected (Fig. $1 \mathrm{~b}, \mathrm{~d}$ and $\mathrm{f}$ ). In the exchanged reaction, relatively larger amount of small DNA fragments was detected than in the normal reaction in the alkaline sucrose gradient. These fragments were probably attached by hydrogen bonding to RF DNA, because they were not detected in the neutral sucrose gradient. The rate of incorporation in the exchanged reaction was constant for $40 \mathrm{~min}$ (Fig. 1g, h; inserted figures) but in the normal reaction the rate was levelled off within $15 \mathrm{~min}$ (Fig. 1i; inserted figure). It is reported that the gene A product of $\phi \mathrm{X} 174$ as well as S13 is only phage-coded protein required in the stage of RF to RF replication. ${ }^{14 \sim 16)}$ Thus, the above results show that the in vitro complementation of gene A products between $\phi \times 174$ and S13 is possible.

\section{Formation of $R F$ to $50 S$ complex}

The formation of $50 \mathrm{~S}$ complex depended on the presence of S13 RF DNA and Fraction II, which was prepared from the cells harvested at $50 \mathrm{~min}$ after phage S13 infection (normal re-

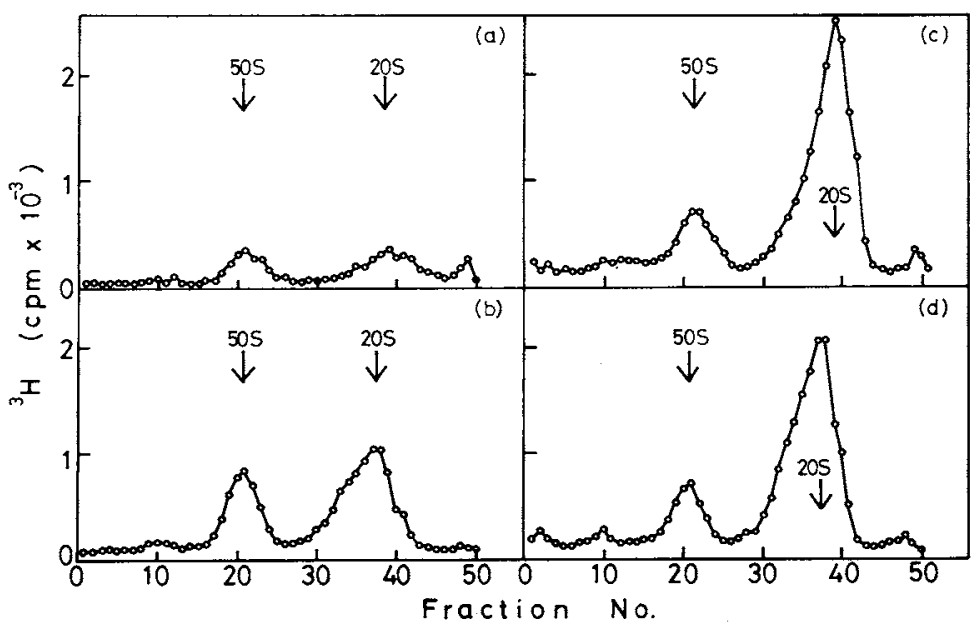

Fig. 2. Product Analysis of RF to 50S Complex System.

Reaction products of S13 RF DNA and Fraction II prepared from S13-infected cells were analyzed by a sucrose gradient III described in MATERIALS AND METHODS. The incubation times of reaction mixtures were $15 \mathrm{~min}$ (a), $60 \mathrm{~min}$ (b), $120 \mathrm{~min}$ (c) and $140 \mathrm{~min}$ (d), respectively. Fractions $1 \sim 2$ represent the $\mathrm{CsCl}$ cushion. S values were estimated by using $\phi \times 174$ mature phage and single-stranded circular DNA as a sedimentation marker. 


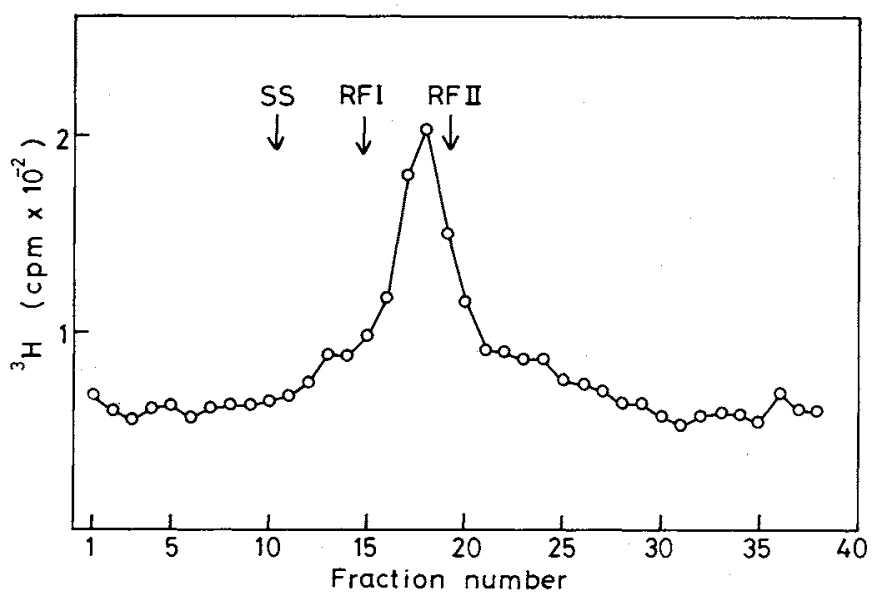

FIG. 3. Characterization of DNA in 50S Region.

$50 \mathrm{~S}$ region in Fig. 2(b) was pooled and the DNA was deproteinized as described in MATERIALS AND METHODS. The purified DNA was then centrifuged in a sucrose gradient I as described in MATERIaLS AND Methods. Arrows indicate the positions of reference $\phi \mathrm{X} 174$ single-stranded DNA, RFI DNA and RFII DNA run in parallel gradient.

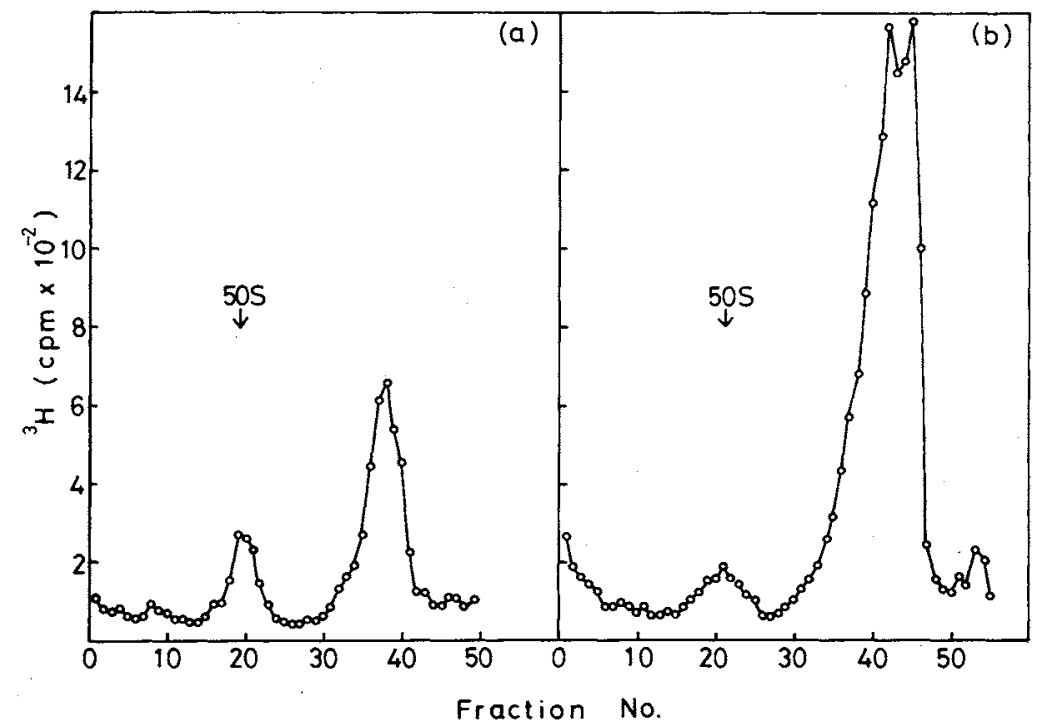

FIG. 4. Product Analysis of Exchanged Reaction in the Stage of RF to 50S Complex.

(a) Reaction product of $\phi$ X174 RF DNA and Fraction II prepared from S13-infected cells.

(b) Reaction product of S13 RF DNA and Fraction II prepared from $\phi$ X174-infected cells. Both reaction mixtures were incubated for $60 \mathrm{~min}$ at $30^{\circ} \mathrm{C}$ and the products were sedimented as described in Fig. 2.

action; data not shown). NEM inhibited the incorporation of dTMP. RF DNA of phage fd did not serve as a template (data not shown). Incorporation of radioactivity into $50 \mathrm{~S}$ complex ceased within $60 \mathrm{~min}$, but synthesis of $20 \mathrm{~S}$ molecules continued for over $120 \mathrm{~min}$ (Fig. $2 \mathrm{a}$, b, c). When the reaction mixture was incubated for $140 \mathrm{~min}$, a small peak sedimenting faster than 50S appeared (Fig. 2d).

After centrifugation, fractions of $50 \mathrm{~S}$ regions were pooled and deproteinized, and the DNA was characterized by neutral sucrose 
gradient centrifugation (Fig. 3). The DNA sedimented at the position between RFI and RFII was the sigma type structure DNA. The DNA from $20 S$ region, analyzed by the same way, sedimented as RFII (data not shown).

When $2 \mathrm{~mm}$ spermidine was added to the reaction mixture in the formation of $\mathrm{RF}$ to $50 \mathrm{~S}$ complex, incorporation of dTMP into S13 RF DNA was observed. However, the products of this reaction were heterogeneous; $17 \sim 20 \mathrm{~S}$ molecules were obtained and $50 \mathrm{~S}$ complex was not formed (data not shown).

Fraction II which was prepared from the cells harvested at $50 \mathrm{~min}$ after phage $\mathrm{S} 13$ infection catalyzed the formation of $50 \mathrm{~S}$ complex from $\phi X 174$ RF DNA. Fraction II prepared from the cells infected with $\phi \times 174$ also catalyzed the formation of $50 \mathrm{~S}$ complex from S13 RF DNA (exchanged reaction). When the product was analyzed by neutral sucrose gradient centrifugation in the exchanged reaction, $50 \mathrm{~S}$ complex was also detected (Fig. 4). The incorporation of radioactivity into $50 \mathrm{~S}$ complex by using Fraction II prepared from $\phi \times 174$ infected cells and S13 RF DNA was slightly lower than that by using Fraction II prepared from the cells infected with S13 and $\phi \times 174$ RF DNA. Furthermore, heterogenous peaks of $17 \sim 20 \mathrm{~S}$ region were detected in the former case (Fig. 4b). It was reported that the formation of $50 \mathrm{~S}$ complex requires all phagecoded gene products except for gene E. ${ }^{18)}$ Thus all phage-coded gene products except for gene $\mathrm{E}$ of $\phi \mathrm{X} 174$ can complement their S13 counterparts and vice versa in the in vitro $50 \mathrm{~S}$ complex formation system.

\section{DISCUSSION}

It is known that gene A protein is the only phage-coded product required in the stage of RF to RF replication. ${ }^{14 \sim 16)}$ This protein nicks the viral strand in RFI DNA uniquely in the gene A region to form RFII. ${ }^{14,15)}$ In this report it was shown that the gene $A$ proteins of bacteriophage $\phi \mathrm{X} 174$ and S13 were able to function reciprocally in the in vitro $\mathrm{RF}$ to $\mathrm{RF}$ replication system. This result would indicate that the DNA sequence recognized by respective gene A proteins is homologous between $\phi \mathrm{X} 174$ and S13, or there is a tolerance in the sequence recognition by these proteins. However, the reaction rate and the amount of short DNA fragments in exchanged reaction were different from that in the normal reaction (Fig. 1). It is not clear why these discrepancies were observed between the two reactions. A possible reason is that the rate of reaction of gene A protein is slow as the conformation of DNA recognized by this protein is slightly different in exchanged reaction.

Recently Borrias et al. have reported that $\phi \mathrm{X} 174$ is able to use the products of bacteriophage $\mathrm{G} 4$ genes $\mathrm{E}, \mathrm{F}, \mathrm{G}$, and $\mathrm{H}$, but only the gene $\mathrm{H}$ product of $\phi \times 174$ is functional in G4 infection. ${ }^{21)}$ The functional relationship between $\phi \mathrm{X} 174$ and $\mathrm{G} 4$ genes was determined by complementation experiments using amber mutants. However, Duguet et al. carried out complementation experiments in vitro between $\phi X 174$ and G4, and found that G4 FRI DNA could be cleaved in a functional manner by $\phi X 174$ gene A product. ${ }^{22)}$ On the other hand, Tessman, ${ }^{16)}$ and Francke and Ray $^{24)}$ showed that the gene A product of $\phi \mathrm{X} 174$ was cis acting in vivo. The result presented here indicates that this protein acts in trans. It is difficult to reconcile the difference of mode of action of the gene $A$ products between in vivo and in vitro. However, Ikeda et al. also concluded that gene A protein is able to act in trans in vitro. ${ }^{25)}$ They showed that gene A protein isolated from cells infected with $\phi \mathrm{X} 174$ gene $\mathrm{E}$ mutant acts in RF DNA prepared from the cells infected with gene $A$ mutant in vitro.

Jenz et al. performed the complementation test in vivo between suppressible mutants of $\phi X 174$ and S13.6) They reported that all but one of S13 or $\phi \mathrm{X} 174$ gene products complement their $\phi X 174$ or S13 counterpart. Since they had no mutant in gene $\mathrm{C}$ of $\phi \mathrm{X} 174$ and in gene $\mathrm{D}$ of $\mathrm{S} 13$, they could not test the complementation activity of these genes between $\phi \times 174$ and S13. On the other hand, all phagecoded gene products except for gene $E$ were 
required for the formation of $50 \mathrm{~S}$ complex from $\mathrm{RF}{ }^{18)}$ In the present report it was shown that all phage-coded gene products except for gene $\mathrm{E}$ of $\phi \mathrm{X} 174$ and S13 were functionally exchangeable with each other in the in vitro formation of $50 \mathrm{~S}$ complex from $\mathrm{RF}$.

Recently, we also found that S13 DNA was replicated by common machinery with $\phi \mathrm{X} 174$ in the stage of SS to RF in vitro. ${ }^{26)}$ However, heteroduplex analysis of the DNAs indicates that mismatches in base pairs distribute over the wide range along the phage genomes. ${ }^{9,10}$ It is likely that the important structure or sequence of viral DNA to be recognized by phage-coded proteins and host cell proteins has not been changed in the process of evolutional divergences.

Acknowledgment. This work was supported in part by a scientific grant from the Ministry of Education, Japan.

\section{REFERENCES}

1) V. Sertic and N. Boulgakov, C. R. Soc. Biol., 119, 1270 (1935).

2) F. M. Burnet, Brit. J. Exp. Path., 8, 121 (1927).

3) S. A. Zahler, J. Bact., 75, 310 (1958).

4) J. H. Spencer, R. Cerny, E. Cerna and D. Delaney, $J$. Virol., 10, 134 (1972).

5) E. S.' Tessman and R. Schleser, Virology, 19, 239 (1963).

6) Y. Jenz, M. Gelfand, M. Hayashi, R. Schleser and E. S. Tessman, J. Mol. Biol., 49, 521 (1970).

7) A. B. Burgess and D. T. Denhardt, J. Mol. Biol., 45, 377 (1969).

8) D. H. Gelfand and M. Hayashi, J. Mol. Biol., 44, 501 (1969).

9) G. N. Godson, J. Mol. Biol., 77, 467 (1973).

10) J. L. Compton and R. L. Sinsheimer, J. Mol. Biol.,
109, 207 (1977).

11) G. N. Godson and R. J. Roberts, Virology, 73, 561 (1976).

12) A. Taketo, Mol. Gen. Genet., 139, 285 (1975).

13) R. R. Meyer, J. Shlomai, J. Kobori, D. L. Bates, L. Rowen, R. McMacken, K. Ueda and A. Kornberg, "Cold Spring Harbor Symposia on Quantitative Biology," Vol. XLIII, Cold Spring Harbor Laboratory, 1979, p. 289.

14) S. Eisenberg, J. G. Scott and A. Kornberg, "Cold Spring Harbor Symposia on Quantitative Biology," Vol. XLIII, Cold Spring Harbor Laboratory, 1979, p. 295.

15) C. S. Yasumoto, J-E. Ikeda, E. Benz, K. J. Marians, R. Vicuna, S. Sugrue, S. L. Zipursky and J. Hurwitz, "Cold Spring Harbor Symposia on Quantitative Biology," Vol. XLIII, Cold Spring Harbor Laboratory, 1979, p. 311.

16) E. S. Tessman, J. Mol. Biol., 17, 218 (1966).

17) C. S. Yasumoto and J. Hurwitz, Proc. Natl. Acad. Sci. U.S.A., 74, 4195 (1977).

18) M. Hayashi, "The Single-Stranded DNA Phages," ed. by D. T. Denhardt, D. Dressler and D. S. Ray, Cold Spring Harbor Laboratory, New York, 1978, p. 531 .

19) S. Wickner, M. Wright, I. Berkower and J. Hurwitz, "Method in Molecular Biology," Vol. VII, ed. by R. B. Wickner, Marcel Dekker, Inc., New York, 1974, p. 195.

20) T. Komano and R. L. Sinsheimer, Biochim. Biophys. Acta, 155, 295 (1968).

21) W. E. Borrias, M. Hagenaar, R. V. D. Brekel, C. Kühlemeijer and P. J. Weisbeek, J. Virol., 31, 288 (1979).

22) M. Duguet, G. Yarranton and M. Gefter, "Cold Spring Harbor Symposia on Quantitative Biology," Vol. XLIII, Cold Spring Harbor Laboratory, 1979, p. 335.

23) B. Francke and D. S. Ray, Virology, 44, 168 (1971).

24) J.-E. Ikeda, A. Yudelevich, N. Shimamoto and J. Hurwitz, J. Biol. Chem., 254, 9416 (1979).

25) K. Watabe, H. Sakai and T. Komano, J. Biochem., 90, (1981) in press. 